\title{
$\mathrm{ASM}$ 을 이용한 전기 이륜차 동력 특성 해석에 관한 연구
}

\author{
이 태 형 ${ }^{1)}$.김 병 우 ${ }^{* 2)}$. 김 용 은 ${ }^{3)}$
}

울산대학교 대학원 전기전자정보시스템공학과 ${ }^{1)}$ - 울산대학교 전기공학부 ${ }^{2)}$ - 자동차부품연구원 차량IT융합연구센터 ${ }^{3)}$

\section{A Study on Power Characteristic of Electric Motoncycle using ASM}

\author{
Taehyung Lee ${ }^{1)}$ Byeongwoo $\mathrm{Kim}^{* 2)} \cdot$ Youngeun $\mathrm{Kim}^{3)}$ \\ ${ }^{1)}$ Graduate School of Electrical Engineering, University of Ulsan, Ulsan 680-749, Korea \\ ${ }^{2}$ School of Electrical Engineering, University of Ulsan, Ulsan 680-749, Korea \\ ${ }^{3)}$ Vehicle-IT Fusion Research Center, Korea Automotive Technology Institute, 74 Yongjeong-ri, Pungse-myeon, \\ Dongnam-gu, Cheonan-si, Chungnam 330-912, Korea
}

(Received 8 June 2012 / Revised 9 October 2012 / Accepted 29 October 2012)

\begin{abstract}
In this paper, we propose that a model based design for an electric motor cycle system using ASM (Automotive Simulation Models). Before prototyping a realistic electric motorcycle, a reliable simulation program is required to test the capacities of the power sources and optimize the parameters of an electric motorcycle. Because ASM is based on Simulink, we can design the drivetrain and powertrain of the vehicle model systems easily. To verify the electric motorcycle system analysis of design parameters such as max power, capacity, state of charge and slope angle is carried out by the simulation and experimental method. The predicted results by the development model were in good agreement with the experimentally obtained results. Therefore, the proposed electric motorcycle model can effectively reduce the expenses during the designing of an electric motorcycle system.
\end{abstract}

Key words : ASM(Automotive Simulaton Models, 오토모티브 시뮬레이션 모델), Simulink(시뮬링크), Electirc motorcycle(전기이륜차), In-wheel motor(인휠모터), Control logic(제어로직), BMS(배터리 매니지먼트 시스템), $\mathrm{MBD}$ (모델기반 설계)

\section{Subscripts}

ASM : automotive simulation models

OBC : on board charger

BMS : battery management system

HILS : hardware in the loop system

ECU : electronic control unit

PMSM : permanent magnetic synchronous motors

MBD : model based design

\footnotetext{
"Corresponding author, E-mail: bywokim@ulsan.ac.kr
}

\section{1. 서 론}

최근 세계적인 이슈인 환경문제와 에너지 문제를 해결하기 위해서 자동차 업계는 전기 동력 기반 차 량에 대한 연구가 활발하다.

현재 전기 자동차는 하이브리드 자동차와 함께 친환경 자동차로서 국내외 다양한 연구가 진행되고 있다. 반면에 전기 이륜차의 경우 전기 이륜차 관련 법규 미흡과 경제성 문제로 인해 전기 자동차에 비 해 활발한 연구가 진행 되지 못하는 실정이다.

기존의 내연기관의 경우 기계기술이 차량의 동력 특성을 크게 좌우한다. 그러나 전기 동력 기반의 차 량의 경우 모터, 배터리, 인버터 등과 같은 전기전자 
장치의 특성에 큰 영향을 받는다. ${ }^{1)}$ 즉, 전기 이륜차 의 핵심 구성 부품에 대한 단품 최적화를 비롯한 각 구성 단품이 전기 이륜차에 시스템에 미치는 영향 을 분석하여 이와 같은 전기 이륜차 시스템을 최적 화 할 수 있다. 그러나 현재까지의 전기 이륜차 연구 는 핵심부품의 특성에 대한 해석보다는 경험에 의 한 연구가 진행되었다. ${ }^{2}$ 특히, 전기 이륜차의 핵심 부품인 전동모터와 배터리는 전기 이륜차의 주행 모드에 따라서 전기적 특성이 급변하게 된다. 그러 므로 전체 시스템을 최적화하기 위해서는 이와 같 은 핵심부품에 대한 전기적 특성을 정량적으로 해 석하여야 한다.

전기 이륜차 부품 모델링에 관련된 기존 연구에 서는 PSAT을 활용한 로직 형태의 전기 이륜차 시스 템을 구성 하였다. ${ }^{3)} \mathrm{PSAT}$ 은 전기, 하이브리드, 연료 전지 등 다양한 라이브러리가 존재한다. 그러나 모 터와 인버터 모델이 세분화 되어 있지 않고, 배터리 셀 단위가 아닌, 팩 단위의 파라미터만을 적용 할 수 있다. 즉, 각 핵심 부품 모델이 세분화 되어 있지 않 고, 모델에 적용 할 수 있는 파라미터 값이 제한적이 기 때문에 모델 최적 설계에 한계가 있다. 또한, 그 동안 국내에서 추진된 전기 이륜차 연구는 선행 연 구 방법이 적용되지 않았고 국내 주행도로 특성을 고려하지 않았다. 이 같은 상태로 개발된 전기 동력 핵심 부품 및 시스템은 내구성능이 현격히 저하되 기 때문에 이를 예방할 수 있는 주행 모드 기반의 이 륜차 설계기준 제시가 요구된다. ${ }^{4)}$

따라서, 본 연구에서는 PSAT보다 세분화된 모델 을 가진 $\mathrm{ASM}$ 을 활용하여 전기 이륜차 핵심 부품인 전동 모터와 배터리, 인버터에 대한 로직 형태의 모 델링을 통해 정량적인 성능 평가와 설계 인자를 제 시 하고자 하였다. 또한, 전기 이륜차의 국내 실제 주행 모드를 고려한 이륜차 모델 설계 가이드라인 을 제시하고자 하였다.

\section{2. 전기 이륜차 시스템 설계}

\section{1 전기 이륜차 구성 및 목표성능}

전기 이륜차의 핵심 부품은 Fig. 1 과 같이 전동 모 터 및 변속모듈, 인버터, 에너지저장 모듈(배터리 \&BMS), 통합제어기로 구성된다.

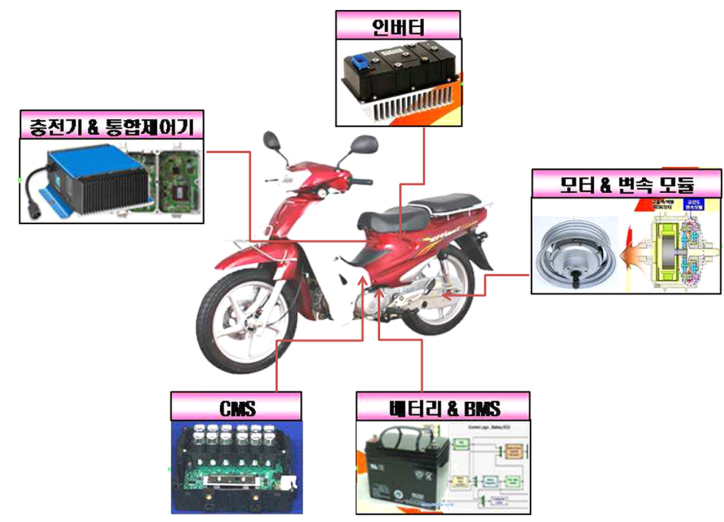

Fig. 1 Components of electric motorcycle

본 연구 대상인 전기 이륜차의 경우 기존 $110 \mathrm{cc}$ 내연기관 엔진의 이륜차를 기반으로 하여 전기 동 력 핵심부품을 다음과 같이 구성하고 있다. 충전 편 의성을 높이기 위해 $\mathrm{OBC}$ 를 적용하였고 리튬이온 배터리팩과 이를 효율적으로 제어하는 고효율/고수 명 $\mathrm{BMS}$ 로 구성된다. 또한, 전기 이륜차의 내구성 및 순간 기동성 향상을 위한 2단 변속기 내장형 PMSM In-Wheel 모터 구동모듈을 적용하였다.

본 연구에서는 $110 \mathrm{cc}$ 내연기관 이륜차를 전기 이 륜차로 재구성하기 위한 것이므로 Table 1 과 같이 기존 내연기관 차량의 성능을 설계 목표로 설정하 였다. 설정한 설계목표 달성 여부를 정량적으로 판 단 할 수 있도록, 국내 내연기관 차량평가기준으로 주로 사용하는 CVS 40 모드를 활용하였다. 최고 주 행속도는 국내 시내도로 주행 속도인 $80 \mathrm{~km} / \mathrm{h}$ 로 설 정, 1 충전 주행거리는 $50 \mathrm{~km} / \mathrm{h}$ 정속 주행 시 $70 \mathrm{~km}$ 로 설정하였다.

등판능력 측정의 경우 국내 지형을 고려하여 $30 \%$

Table 1 Design objective of electric motorcycle

\begin{tabular}{|c|c|c|}
\hline Parameter & Value & Unit \\
\hline Maximum rating speed & 80 & $\mathrm{~km} / \mathrm{h}$ \\
\hline $\begin{array}{c}\text { Cruising range } \\
\text { (Constant 50km/h) }\end{array}$ & 70 & $\mathrm{~km}$ \\
\hline $\begin{array}{c}\text { Gradeability } \\
\text { (Slope 30\%) }\end{array}$ & 14 & $\mathrm{~km} / \mathrm{h}$ \\
\hline CVS 40 & 90 & $\mathrm{~km}$ \\
\hline Nominal voltage & 73 & $\mathrm{~V}$ \\
\hline Maximum weight & 285 & $\mathrm{~kg}$ \\
\hline Wheel size & 576 & $\mathrm{~mm}$ \\
\hline
\end{tabular}


경사에서 $14 \mathrm{~km} / \mathrm{h}$ 의 주행속도를 목표 값으로 설정하 였고, Nominal voltage는 $73 \mathrm{~V}$, 이륜차의 총 무게는 운전자 포함 $285 \mathrm{~kg}_{\mathrm{f}}$ 으로 설정하였다.

\section{2 핵심 구성 부품 모델링}

본 연구에서는 핵심 구성 부품 모델링을 위하여 $\mathrm{dSPACE}$ 사의 ASM 프로그램을 사용하였다. ASM 프로그램은 차량 어플리케이션의 리얼타임 시뮬레 이션을 위한 Open Simulink 모델로 MATLAB $/$ Simulink 기반 $3^{\text {rd }}$ 프로그램이다. 그러므로 Carsim 과 같은 타 프로그램과의 호환성이 우수하며 $\mathrm{ECU}$ 테스트 및 HILS 연구에 사용할 수 있는 것이 강점이 다. 또한, 전기 자동차 모델링을 위한 전기 부품 모 델을 지원하기 때문에 본 연구에 적합하다.

본 연구 대상인 전기 이륜차의 부품 모델링을 위 해서 ASM에서 지원하는 전기 부품 모델을 기반으로 하는 시스템 모델을 Fig. 2 와 같이 생성하였다. ASM 프로그램은 리튬이온 배터리, 전동 모터(DC, BLDC, PMSM), 인버터, 컨트롤러, 다양한 보조 장치 모델 라 이브러리가 존재한다. 이 중에서 전기 이륜차 부품 과 가장 유사한 모델을 활용하여 시스템 구성을 하였 다. 본 논문에서는 전기 이륜차 핵심 부품 중 가장 중 요한 모터와 배터리 모델을 중점적으로 다루었다.

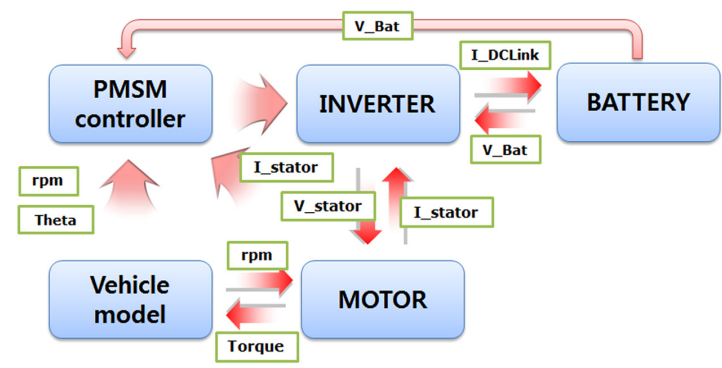

Fig. 3 Flow chart of control logic

모터 모델은 Fig. 4에서 볼 수 있듯이 전류 계산로 직, 역기전압 계산로직, 토크 계산로직으로 나눌 수 있다. 모터 전류는 모터 전압과 모터 각속도, 로터의 각도를 변수로 하여 출력되고 역기전압은 로터의 각도와 각속도, 자속에 의해 결정된다. 또한, 토크의 경우 $\mathrm{d}$ 축과 $\mathrm{q}$ 축의 전류 값을 변수로 하여 정해진다. 모터 모델에서 계산된 출력 값들은 신호 버스라인 을 통해서 ASM signal 모델로 종합된다.

본 연구에서의 내연기관 기반의 이륜차 대비 비 슷한 전기 이륜차 목표 사양을 달성하기 위해서 동 력 부하 특성을 해석하였다. 휠 직경이 $576 \mathrm{~mm}$ 이므 로 $30 \%$ 등판 주행에서 $14 \mathrm{~km} / \mathrm{h}$ 를 만족하기 위해서 Fig. 5(a)의 부하점 (1)에서는 모터가 $138 \mathrm{rpm}$ 으로 구 동하여야 한다. 그리고 평지주행에서 최고 속도

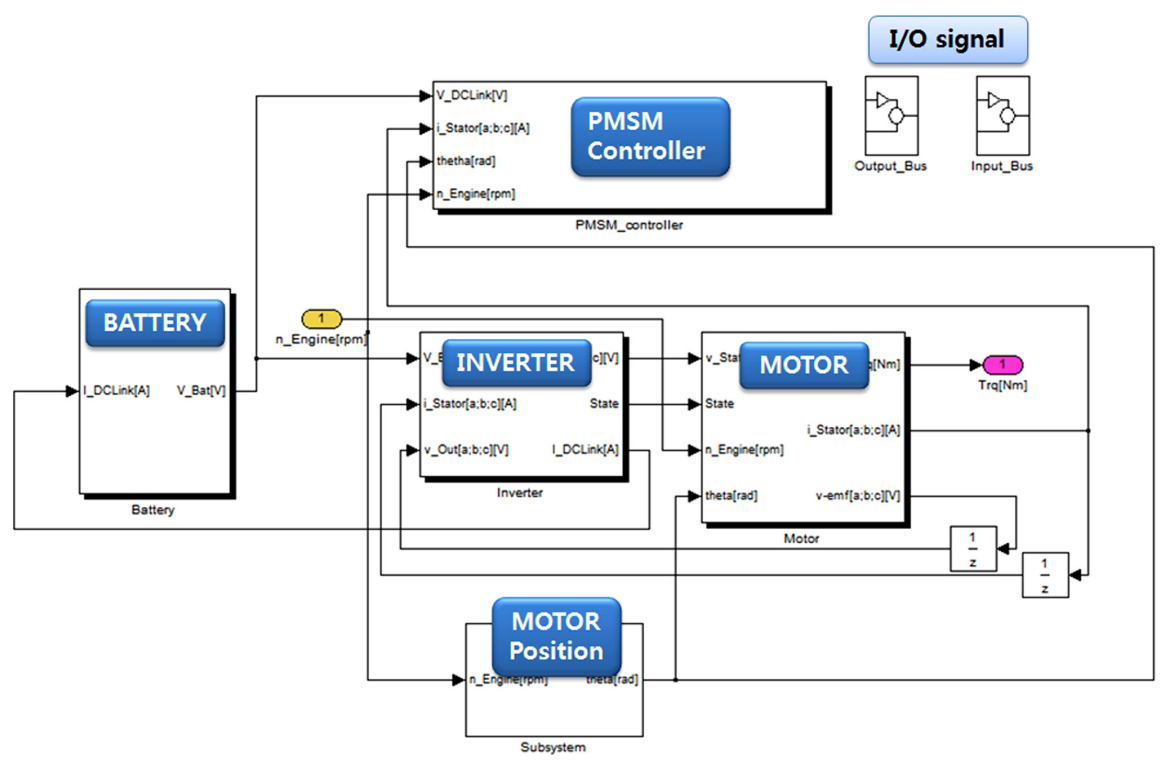

Fig. 2 Components model of electric motor cycle 


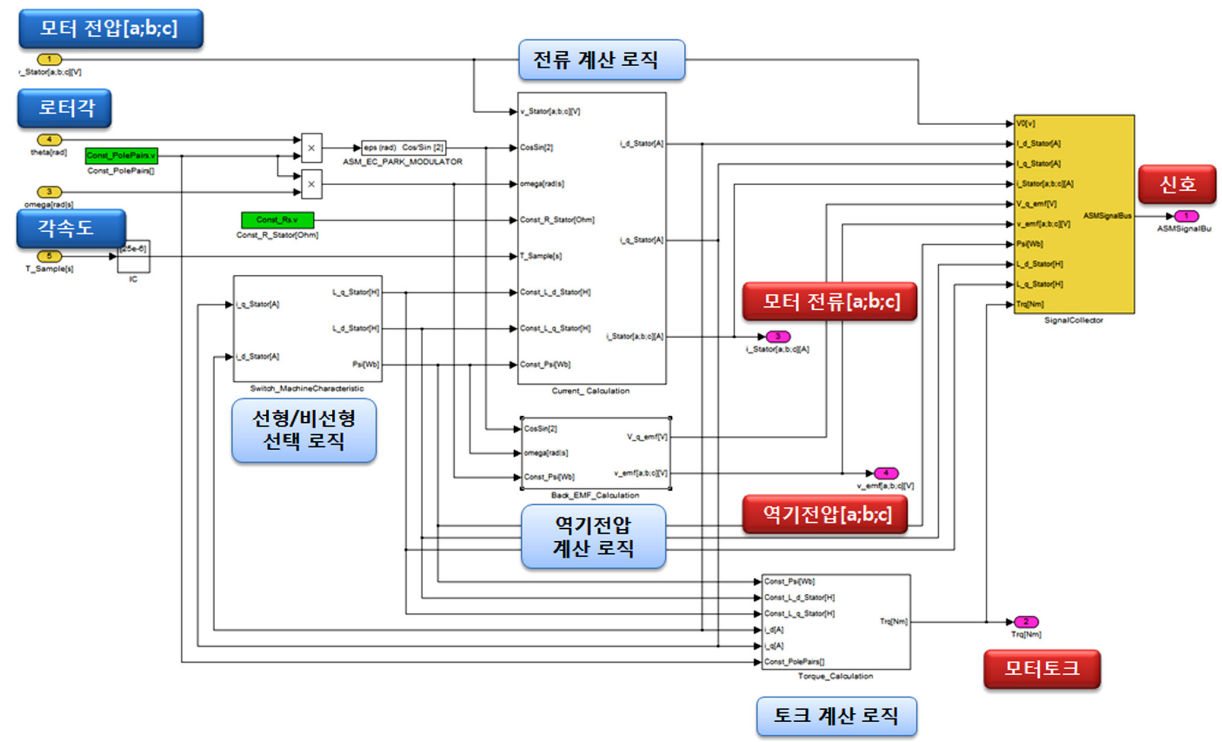

Fig. 4 Control logic of driving motor

$80 \mathrm{~km} / \mathrm{h}$ 를 만족하기 위한 부하점 (2)에서는 모터가 $737 \mathrm{rpm}$ 으로 구동하여야 한다. 부하점 (1), (2)에서 전 동모터의 구동 토크는 식 (1)을 이용하여 구한 구름 저항, 식 (2)를 이용하여 구한 공기저항과 식 (3)을 이용해 구한 구배저항을 모두 더한 전체 부하 저항 보다 커야 한다. 각 상태에서의 저항력과 필요한 모 터의 특성을 Table 2에 나타내었다.

$P_{\text {rolling }}=C_{r} W$

$R_{\text {air }}=\frac{1}{2} \rho\left(C_{d} A\right) V^{2}$

$R_{\text {slope }}=W \sin \alpha$

where $\quad \mathrm{C}_{\mathrm{r}}$ : Rolling resistance coefficient

$\mathrm{C}_{\mathrm{d}}$ : Drag resistance coefficient

W : Weight of vehicle

A : The frontal area

$\mathrm{V}$ : Velocity of vehicle

Fig. 5(b)의 실제 사용한 모터의 최대토크 $239 \mathrm{~N} \cdot \mathrm{m}$ 는 위에서 계산된 토크 $232.1 \mathrm{~N} \cdot \mathrm{m}$ 보다 크기 때문에 설계기준을 만족하였다. 또한 부하점 (2)에서의 실 제 토크는 $46 \mathrm{~N} \cdot \mathrm{m}$ 으로 계산된 토크 $45.7 \mathrm{~N} \cdot \mathrm{m}$ 보다 크 므로 설계 기준을 만족함을 알 수 있다.

배터리는 라이브러리에서 제공하는 multicell model
Table 2 Total resistance \& Required motor specifications

\begin{tabular}{|c|c|c|}
\hline & 부하점 (1) & 부하점 (2) \\
\hline 모터회전수 $(\mathrm{rpm})$ & 138 & 737 \\
\hline 구름저항 $(\mathrm{N} \cdot \mathrm{m})$ & 9.7 & 9.7 \\
\hline 공기저항 $(\mathrm{N} \cdot \mathrm{m})$ & 1.3 & 36 \\
\hline 구배저항 $(\mathrm{N} \cdot \mathrm{m})$ & 221.1 & 0 \\
\hline Required torque $(\mathrm{N} \cdot \mathrm{m})$ & $>232.1$ & $>45.7$ \\
\hline Required power $(\mathrm{kW})$ & 3.54 & 3.50 \\
\hline
\end{tabular}

을 사용하였다. multicell model 최대 500 개의 셀의 직렬연결이 가능하고 각각의 셀의 전압을 계산할 수 있다. 본 연구에서는 최소 셀 전압 $3.5 \mathrm{~V}$ 에서 최대 셀 전압 $4.15 \mathrm{~V}$ 의 리튬 폴리머 배터리로 설계하였다. 팩 구성은 셀 20 개를 직렬 연결하였고 총 2 개의 팩 을 병렬로 연결하였다. Fig. 6(a)는 배터리 모델의 로 직을 나타낸다. 배터리 모델은 크게 배터리 전압과 부하전류, SOC를 계산하는 Battery cell model과 열 발생과 열손실을 계산하는 터미널 전압 모델, 배터 리 레퍼런스 전압과 비교하여 각 셀의 전압차이를 계산하는 Delta model로 나눌 수 있다. 터미널 전압 모델의 경우, 모터에서 요구하는 전류와 Thermal model에서 계산된 배터리 온도를 변수로 식 (4)를 활용하여 배터리 셀의 전압, 손실전압, 저항을 계산 하였다. 


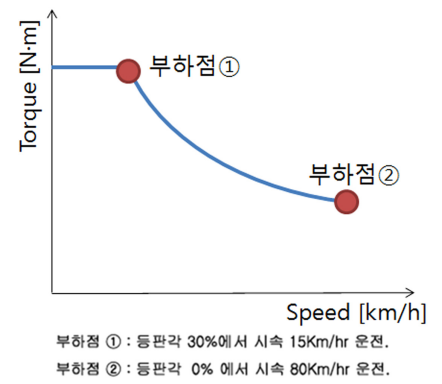

(a)

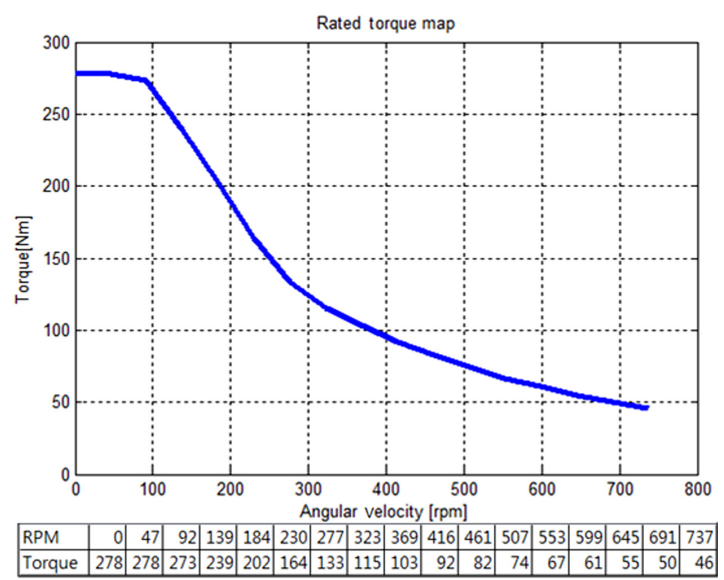

(b)

Fig. 5 Torque map of driving motor

$$
\begin{aligned}
V_{\text {Bat }}= & V_{\text {Bat }, 0}-V_{\text {Loss }} \\
V_{\text {Bat }, 0}= & n_{\text {cell }} V_{\text {cell }}(S O C) \\
V_{\text {Loss }}= & \frac{1}{C_{D L}} \int\left(I_{\text {Bat }}-\frac{V_{C D L}}{R_{D L}}\right) \\
& +\frac{1}{C_{D L}} \int\left(I_{\text {Bat }}-\frac{V_{C D i f f}}{R_{\text {Diff }}}\right) \\
& +I_{\text {Bat }} R_{\text {Bat }}\left(S O C, I_{\text {Bat }}, T_{\text {Bat }}\right)+\frac{d I_{\text {Bat }}}{d t} L_{\text {Bat }}
\end{aligned}
$$

where $\quad \mathrm{V}_{\text {Bat }}$ : Battery terminal voltage

$$
\mathrm{V}_{\text {Bat }, 0}: \text { Balanced voltage }
$$$$
\mathrm{V}_{\text {Loss }} \text { : Loss voltage }
$$

Thermal model의 경우 식 (7)을 통해서 배터리의 열 발생과 열손실을 계산하여 현재 배터리 온도를 계산할 수 있다. 열 발생은 배터리 전류와 손실전압 에 대한 내부손실과 배터리의 화학 반응, 배터리 내 가스 발생으로 인한 손실반응에 의해 발생한다. 또
한, 열손실은 열복사에 의해 일어나며 총 열 발생에 서 열손실을 감하여 $\mathrm{P}_{\mathrm{w}}$ 를 계산할 수 있다. Thermal model에서 계산한 배터리 온도 값은 터미널 전압 계 산의 변수로 사용한다.

$$
T_{\text {Bat }}=T_{B a t, 0}+\frac{1}{c_{B a t} m_{B a t}} \int P_{W} d t
$$

\section{where CBat: Heat capacity} mBat : Battery mass

$\mathrm{SOC}$ 계산 로직의 경우 식 (8)을 활용하여 부하전 류 로직에서 계산된 손실전류와 충전 혹은 방전 시 배터리 전류를 변수로 하여 계산한다. 배터리 전류 와 손실전류의 차이가 0 보다 크면 부하전류는 충전 상태이며 0 보다 작으면 부하 전류는 방전상태를 나 타낸다.

$$
S O C=S O C_{0}+\frac{1}{K_{N}} \int\left(I_{\text {Terminal }}-I_{\text {Loss }}\right) d t
$$

where $K_{N}$ : Nominal capacity of battery

리틈 이온 배터리의 경우 $20 \%$ 이상 과다 방전은 배터리 수명에 악영향을 미치므로 전압사용범위를 $\mathrm{SOC} 20 \%$ 에 해당하는 $3.5 \mathrm{~V}$ 로 제한하였다. $50 \mathrm{~km} / \mathrm{h}$ 정속 주행 시 주행거리 $70 \mathrm{~km}$ 를 달성하기 위해서는 총 84 분을 주행할 수 있어야 한다. $50 \mathrm{~km} / \mathrm{h}$ 정속 기준 배터리 전류는 $20 \mathrm{~A}$ 로 SOC $100 \%$ 에서 $20 \%$ 까지의 사 용 범위와 방전특성을 감안하여 배터리 용량은 총 $40 \mathrm{Ah}$ 로 설정하였다.

\section{3. 주행 특성 시뮬레이션}

위와 같이 전기이륜차 모델을 설계 후 모델 검증 을 위해서 최대 속도 측정 및 $50 \mathrm{~km} / \mathrm{h}$ 정속주행 시 주 행거리, $30 \%$ 등판능력 테스트에 대한 시뮬레이션 및 실차 테스트 결과를 비교하였다. 또한, 내연기관 이 륜차에서 연비측정으로 사용하는 CVS 40 주행 모 드를 사용하여 1 충전 주행거리 시뮬레이션 및 실차 테스트 결과를 비교하였다. 모든 테스트에서 배터 리 보호를 위해 최소 충전 상태인 $20 \%$ 잔량에서는 시스템 구동을 중지하였다.

그 결과 최대 속도 측정에서는 Fig. 7에서 볼 수 있 듯이 $84 \mathrm{~km} / \mathrm{h}$ 로 실차 테스트 결과 $82.1 \mathrm{~km} / \mathrm{h}$ 와 유사한 


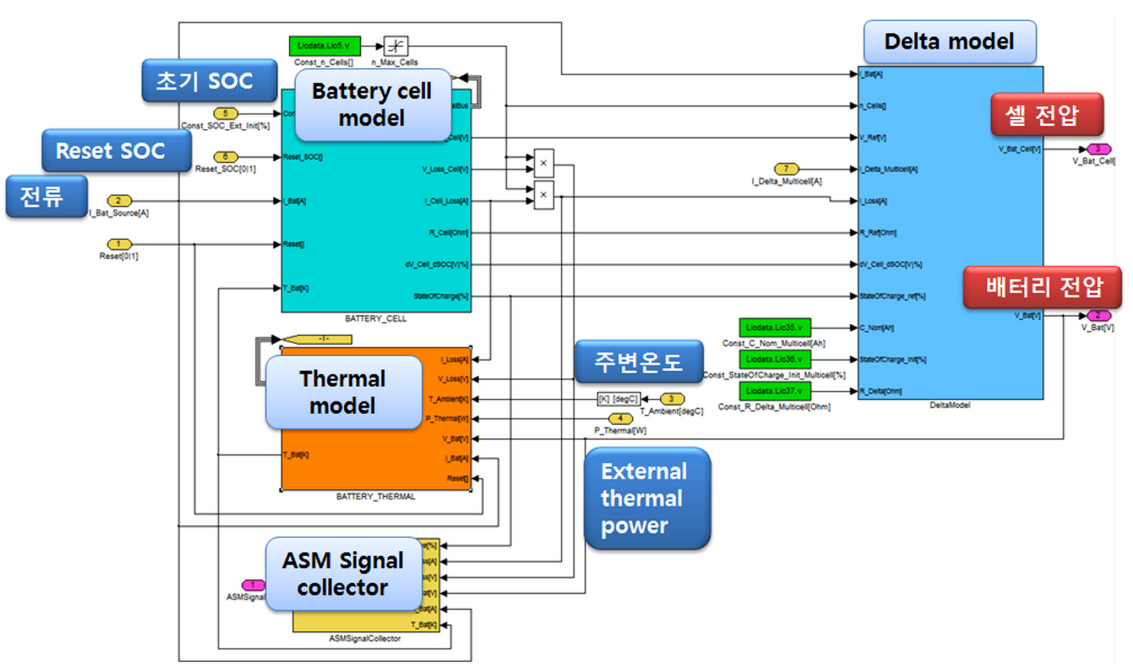

(a)

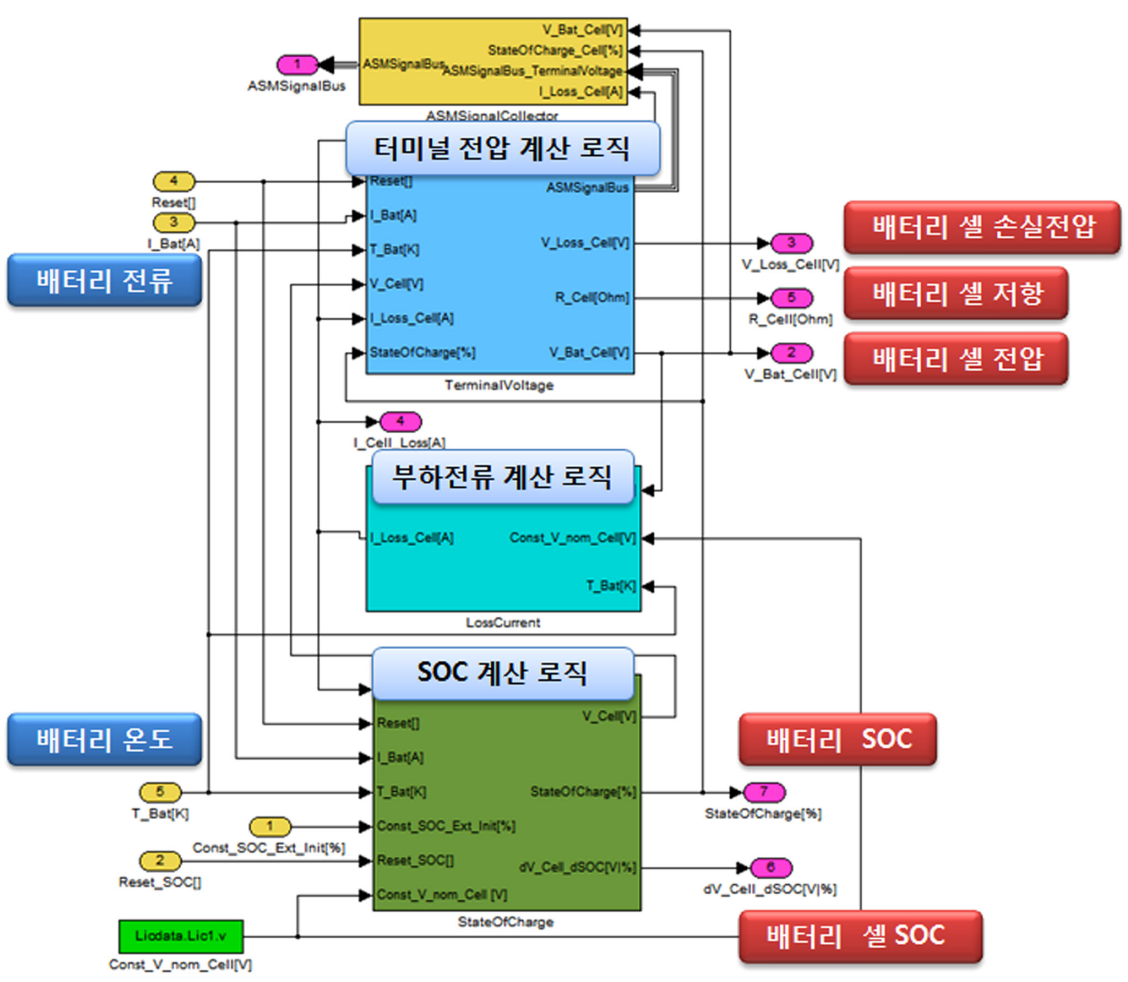

(b)

Fig. 6 Logic structure of battery model

결과를 얻을 수 있었다. 실차 테스트의 경우 전기 이 륜차에 장착한 GPS상의 속도를 측정하였다. $50 \mathrm{~km} / \mathrm{h}$ 정속주행 테스트의 경우 일반적으로 사용되는 SOC 가 $20 \%$ 에서 $80 \%$ 범위에서 전압 강하를 확인 후 주
행가능 거리를 측정하였다. 이 때, 배터리 방전 전류 가 약 $20 \mathrm{~A}$ 로 일정하게 방출되며 총 이동 거리는 $91.67 \mathrm{~km}$ 이다. 이 값은 실차 테스트 결과 값인 $87.50 \mathrm{~km}$ 와 근접한 결과를 나타낸다. 




Fig. 7 Graph of top speed simulation test

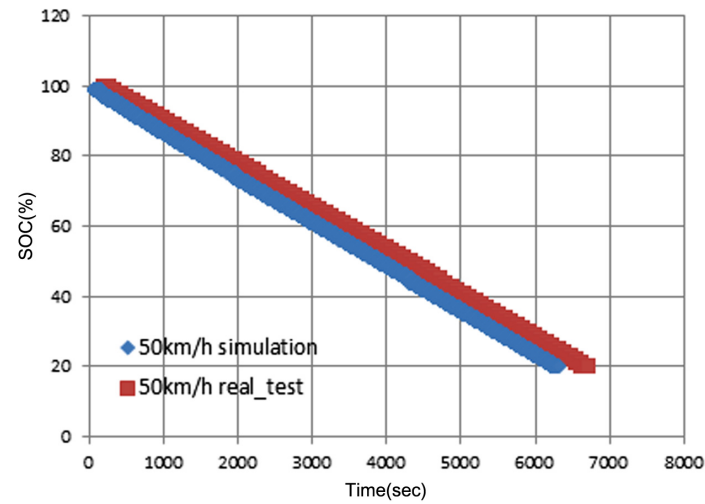

Fig. 8 Graph of SOC - time at $50 \mathrm{~km} / \mathrm{h}$ constant speed test

등판능력 테스트는 Fig. 9 와 같이 $10 \%, 20 \%, 30 \%$ 경사로에서의 최대 속도 값을 측정하였다. Tabe 4 는 시뮬레이션과 실차 테스트 결과이다. 시뮬레이션 결과 값이 실차 테스트 결과 값 보다 약간 높게 측정 되었다. 이는 실차 테스트의 경우 $10 \%, 20 \%, 30 \%$ 에 정확하게 맞는 구배가 아니라 근접한 구배의 등판 로이기 때문으로 판단된다.

도시 주행모드인 CVS 40 주행 모드는 전기 이륜
Table 3 Distance of $50 \mathrm{~km} / \mathrm{h}$ constant speed test

\begin{tabular}{|c|c|c|c|}
\hline 항목 & 시뮬레이션 & 실차테스트 & 주행시간 \\
\hline $50 \mathrm{~km} / \mathrm{h}$ & $70.5 \mathrm{~km}$ & $71.0 \mathrm{~km}$ & 86 분 \\
\hline
\end{tabular}

Table 4 Speed of $10 \%, 20 \%, 30 \%$ climbing test

\begin{tabular}{|c|c|c|c|}
\hline & $10 \%$ & $20 \%$ & $30 \%$ \\
\hline 시뮬레이션 & $34.8 \mathrm{~km} / \mathrm{h}$ & $30 \mathrm{~km} / \mathrm{h}$ & $23.2 \mathrm{~km} / \mathrm{h}$ \\
\hline 실차테스트 & $34.7 \mathrm{~km} / \mathrm{h}$ & $28.4 \mathrm{~km} / \mathrm{h}$ & $21.7 \mathrm{~km} / \mathrm{h}$ \\
\hline
\end{tabular}

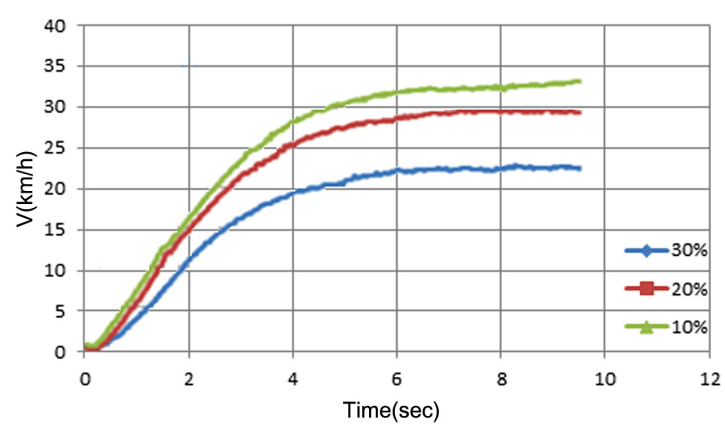

Fig. 9 Graph of climbing simulation test

Table 5 Distance of CVS40 mode test

\begin{tabular}{|c|c|c|c|}
\hline 항목 & 시뮬레이션 & 실차테스트 & 주행시간 \\
\hline CVS40 & $91.96 \mathrm{~km}$ & $89.8 \mathrm{~km}$ & 250 분 \\
\hline
\end{tabular}

차가 Fig. 10 과 같이 가 감속을 반복하는 테스트 주 행 모드이며 평균 차속은 $18.35 \mathrm{~km} / \mathrm{h}$, 최고 속도 $50 \mathrm{~km} / \mathrm{h}$, 주행시간 195 초/회, 주행거리 $1.013 \mathrm{~km} /$ 회로 구성되어 있다. 설계한 핵심 부품 모델을 시뮬레이 션 하여 CVS 40 주행 모드에 적용한 결과 총 이동가 능 거리 $91.96 \mathrm{~km}$ 를 얻었다. CVS 40 주행모드 실차 테스트 결과 값은 $89.8 \mathrm{~km}$ 로 비슷한 결과를 나타내 었다.

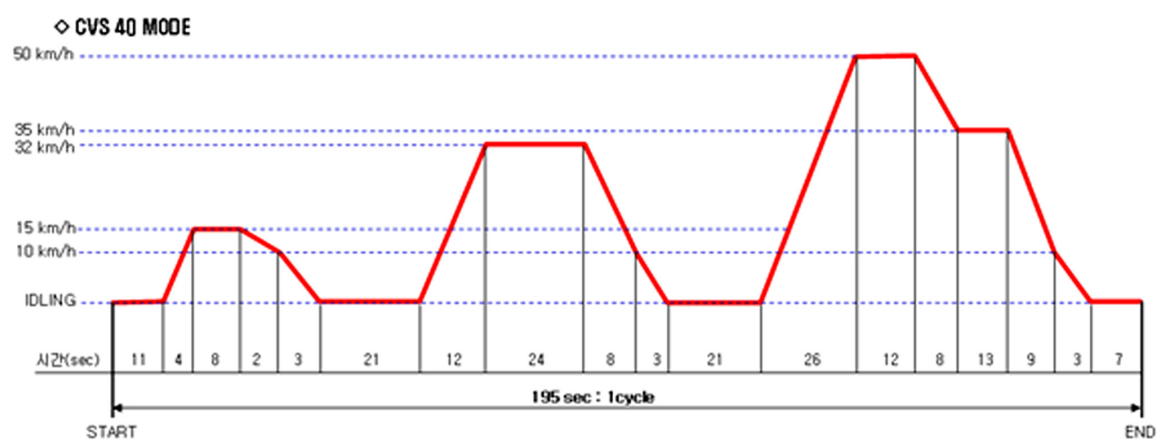

Fig. 10 CVS 40 test mode 


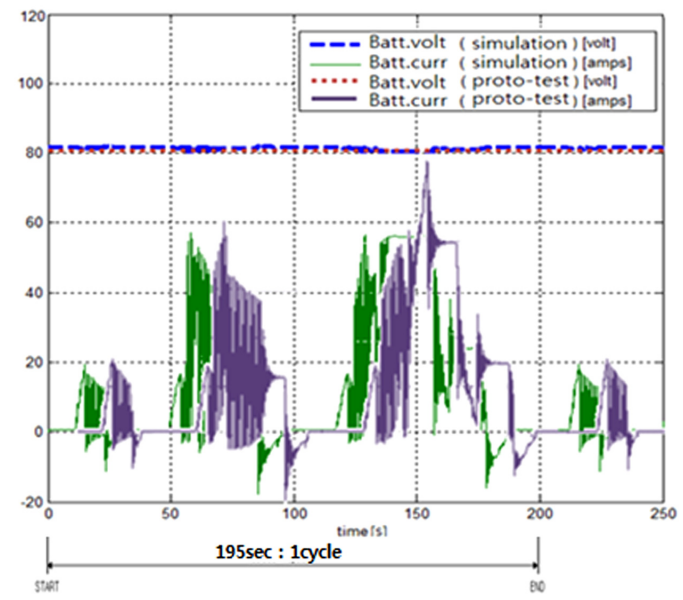

Fig. 11 Battery Volt \& Current graph of CVS 40 mode test

\section{4. 결 론}

본 연구에서는 ASM 모델을 활용한 이륜차 핵심 부품 모델을 제안하였다. 전기 이륜차 모델 신뢰성 검증을 확인하기 위해 시뮬레이션 실시 후 결과 값 과 실차테스트 결과 값을 비교를 실시하였다. 또한, 이를 통해 전기 이륜차의 성능을 정량적으로 평가 할 수 있는 기반을 마련하였다. 전기 이륜차 모델 설 계 시 $\mathrm{MBD}$ 기법을 사용하여 알고리즘의 수정 및 검 증용이 등의 모델의 실용성을 극대화 시킬 수 있었 고 전기 이륜차의 개발기간 단축 및 모델 재사용성, 정확성을 확인할 수 있었다.

기존의 내연기관 전기 이륜차의 동력특성을 기준 으로 국내 시내도로지형을 만족하는 전기 이륜차 핵심부품 모델의 설계 가이드라인을 다음과 같이 얻을 수 있었다. 시뮬레이션 결과 최대속도 $80 \mathrm{~km} / \mathrm{h}$, $50 \mathrm{~km} / \mathrm{h}$ 정속주행 1 충전 주행거리 $70 \mathrm{~km}, \mathrm{CVS} 40$ 모 드 1 충전 주행거리 $90 \mathrm{~km}$ 를 만족하는 배터리는 인가 전압 $72 \mathrm{~V}$ 에서 용량 $40 \mathrm{Ah}$, 최대 정격 전류 $70 \mathrm{~A}$ 가 요 구되었다. 또한, 위의 배터리 조건을 만족하고 실제 도로주행 등판 각도 30 도를 극복하기 위해서 정격
토크 $278 \mathrm{~N} \cdot \mathrm{m}$, 정격출력 $4.09 \mathrm{~kW}$ 가 적합함을 확인하 였다.

본 연구에서는 $\mathrm{ASM}$ 을 활용한 전기 이륜차 핵심 부품 모델 검증과 정량적 설계 가이드라인을 제시 할 수 있었다. 향후, 연구에서는 모델의 정확도를 더 높여 갈 것이며 이 모델을 활용하여 결함 시나리오 에 대한 Fail safety 연구를 진행하고자 한다.

\section{후 기}

본 연구는 지식경제부 산업원천기술개발사업과 한양대 IT자동차 융합 고급인력 양성센터 사업 일 환으로 수행된 논문입니다.

\section{References}

1) C. Meifen and J. Egashira, "High Efficiency Control of IPMSM for Electric Motorcycles," Power Electronics and Motion Control Conference, pp.1893-1897, 2009.

2) B. S. Kil, G. C. Kim, E. Lee and S. H. Oh, "The Analysis of a Electric Scooter's Performance through Motor and Battery Capacity Changing," KSAE Annual Conference Proceedings, KSAE 09-A0533, 2009.

3) J. K. Choi, "A Study on the Power Characteristics Analysis of Electric Motorcycle," The Korea Academia-Industrial Cooperation Society, Vol.12, No.11, pp.5156-5163, 2011.

4) C. S. Hearn, M. C. Lewis, R. C. Thompson and R. G. Longoria, "Modeling and Evaluation of a Plug-in Hybrid Fuel Cell Shuttle Bus," IEEE Vehicle Power and Propulsion Conference VPPC '09, pp.221-228, 2009.

5) ASM Electric Components Reference Manual, pp.35-42, 51-57, 2010. 